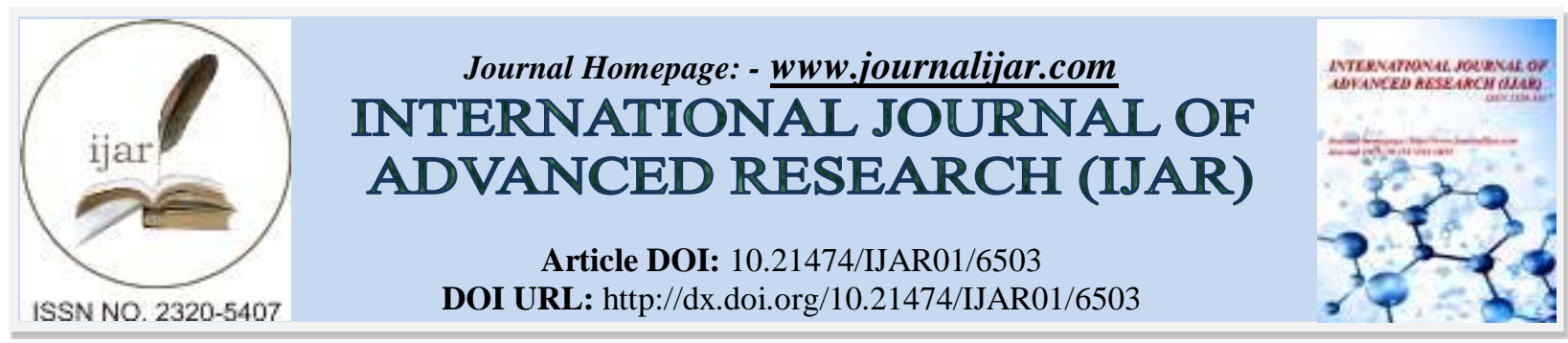

RESEARCH ARTICLE

\title{
THE ISOLATION AND BIOLOGICAL CHARACTERIZATION OF BACTERIOPHAGES LYTIC TO GEORGIAN STRAINS OF RALSTONIA SOLANACEARUM RACE 3 BIOVAR 2.
}

\author{
Lashkhi N. $^{1}$, T. Kokashvili ${ }^{1}$, T. Eliashvili ${ }^{1}$, T. Koberidze ${ }^{1}$, G. Tsertsvadze $^{1}$, M. Muradashvili ${ }^{2}$, G. \\ Meparishvili $^{2}$, Z. Sikharulidze ${ }^{2}$ and M. Tediashvili ${ }^{1}$. \\ 1. George Eliava Institute of Bacteriophages, Microbiology and Virology, Tbilisi, Georgia. \\ 2. Institute of Plant Pathology and Biodiversity, Batumi Shota Rustaveli State University, Batumi, Georgia.
}

\section{Manuscript Info}

\section{Manuscript History}

Received: 11 December 2017

Final Accepted: 13 January 2018

Published: February 2018

Key words:-

Plant Diseases, Ralstonia solanacearum, potato, biological control, bacteriophage, antibiotics.

\section{Abstract}

Antibiotic sensitivity revealed that all isolates were fully susceptible to enerofloxacin, ciprofloxacin, while all isolates were fully resistant to penicillin. E. coli serogrouped isolates were subjected to PCR for detection of Stx 1 and Stx 2 genes. 3 out of 7 serogrouped isolates $(42.85 \%)$ were carried Stx2 gene (O55 and O27 from contact human and 086 from mastitic milk) while Stx 1 gene was not detected . phylogenetic analysis for the sequence data of the Sxt2 gene of E. coli serogroupes revealed that $S x t 2$ gene isolated from mastitic milk of cattle is closely identical ( $100 \%$ identity) to $S x t 2$ gene isolated from contact human. In Conclusion, isolation of STEC from cattle might have potential pathogenicity for human. So that contact human should use sound hygienic measures during milking and management of these animals to avoid zoonotic infection.

Ralstonia solanacearum is a soilborne bacterial pathogen, distributed in tropical, subtropical and some temperate regions, causing serious diseases of strategic crops, such as potato, tomato, banana etc. Control of plant infections caused by R.solanacearum is a challenging issue. Phage preparations can be considered as effective tool for prevention of infection spread in the environment and in the seed plant material. Since first report on detection of $R$. solanacearum in Georgia up to 60 strains have been collected, majority attributed to race 2 biovar 3 . The presented work aimed at isolation of bacteriophages specific to Georgian strains of $R$. solanacearum and study their biological properties in order to select phages for strain subtyping and for infection control. During 2015-2017 enrichment of environmental samples with 40 selected isolates of $R$. solanacearum and subsequent processing of primary mixtures resulted in obtaining of 25 individual Rs phages. Initial grouping of phages was done based on negative colony morphology, lytic spectrum and virion ultrastructure. Transmission electron micrioscopy (TEM) revealed the prevalence of Myoviridae type morphology among Rs phages, although single phages were attributed to Podoviridae and Siphoviridae families. The Rs phages showed diverse host range. The phage - and antibiotic susceptibility profiles of $R$. solanacearum strains were compared and showed no correlation between these two characteristics. Ten 
bacteriophages with overlapping spectrum were characterized in more details, including lytic activity in liquid culture and stability in various natural and artificial solutions. The mixture of 4 selected phages was composed for use in in vivo challenge experiments.

Copy Right, IJAR, 2018,. All rights reserved.

\section{Introduction:-}

Among the top 10 species of phytopathogenic bacteria with high economic importance $R$. solanacerum has been ranked as the second most serious pathogen (Mansfied et al, 2012; Champoiseau et al, 2009). R. solanacearum is a soilborne bacterium, widely distributed in tropical, subtropical, and some temperate regions of the world. This organism causes rapid and often fatal vascular wilt disease in up to 400 plant species worldwide, including strategic crops. $R$. solanacearum is a causative agent of brown rot of potato, bacterial wilt of tomato,tobacco and eggplant, diseases of banana and ornamental plants etc. The harvest losses due to R.solanacearum infections can vary widely depending on the host plant, climate and soil type, also particular bacterial strain. For potato, tomato and banana the loss can reach 90-100\% (Elphistone, 2005).

$R$. solanacearum is a highly heterogenous bacterial pathogen and has been divided into five races and six biovars based on host range and carbon source utilization. Molecular typing in conjunction with phenotyping traits provided 4 phylotypes, corresponding to the geographical origin ofstrains (Fegan \& Prior, 2005).The strains of race 1 R.solanacearum have a broad host range including tobacco and bananas, and are found in tropical and subtropical environment. The strains of race 3, biovar 2 are spread in countries of subtropical and temperate regions such as Central and Southern Europe, Great Britain, North Africa, Canada etc, causing significant economic losses. $R$. solanacearum is included in the CDC's list of select agents with the potential to pose a severe threat to human, animal or plant health, or their products (https://www.selectagents.gov/SelectAgentsandToxinsList.html).

Diseases, caused by R.solanacearum, were registered in Georgia first time in 2010 during the field surveys, when in several regions of West Georgia up to $100 \%$ loss in greenhouse- and field-grown tomatoes was reported (Meparishvili et al, 2012). Interestingly, indirect detection of the pathogen in the water environment of Georgia was done earlier based on presence of R.solanacearum - specific phages, as indicators (Lashkhi et al, 2003). In 201214 potato brown rot was detected in home gardens as well as commercial potato plantations in the West and South Georgia. Bacterial wilt symptoms were reported also on tomatoes, eggplants, peppers and ornamental plants in different regions of Georgia. The presence of $R$. solanacearum in infected material was shown by convectional bacteriology and by species- specific PCR (Muradashvili et al. 2014; Muradashvili et al, 2015). According to the Endoglucanase (Egl) sequencing ( M.Muradashvili et al, 2018, in press) the most strains isolated in potato industrial region in South Georgia belong to a most important single phylogenetic group of the race 3 biovar 2 (Phylotype IIB/Sequevar 1 (IIB-1) designation), which is supposed to be spread with the worldwide trade of seed potato.

Control of bacterial infections of plants in general, and those caused by R.solanacearum in particular, is a challenging issue. This is related to pathogen's capability to grow endophytically in infected plants, its survival and spread though water and soil and colonization of weeds. Different approaches involving physical, chemical, and biological methods have been elaborated and used in the fight against bacterial wilt. Still disease outbreaks are difficult to control due to lack of effective bactericides and due to development of resistance to antibacterial compounds. A number of studies identified some promising biological control agents (BCAs), which are mainly avirulent strains of $R$. solanacearum and Pseudomonas spp., also some Bacillus spp., Streptomyces spp., etc (Ramesh \& Phadke,2012; Ramesh et al, 2015;). Bacteriophages lytic to $R$. solanacearum are considered as a potential effective tool for prevention of infection spread in the environment and for treatment of seed plant material. A number of studies have been done to assess the biocontol potential of phages for different plant diseases [Balog et al, 2010]. Various phages infecting $R$. solanacearum have been isolated from soil and water, also from diseased plants (Toyeda et al, 1991; Balogh, 2010). Some phages have been characterized in details, including the full genome analysis, (Yamada et al, 2007; Fujiwara et al, 2011; Bae et al, 2010, Matsui et al, T.2017). Majority of R.solanacearum phages appeared to be quite similar and had restricted host range. Only few phages demonstrated the ability to efficiently control bacterial wilt in planta. High rate of bacterial resistance, impact of environmental 
factors and weak persistence in the plant environment is considered an important problem (Balogh et al, 2010). Therefore search for broad range lytic phages with suitable properties remains to be a an important goal.

The aim of the present work was isolation of bacteriophages specific to $R$. solanacearum from environmental samples and characterize them by basic biological properties. Determination of susceptibility of Georgian isolates of $R$. solanacearum to specific bacteriophages and the comparison with the susceptibility to antibiotics was another aim of the study. The lytic phages with broad overlapping spectrum (or their combinations) can be applied as an efficient tool for the detection and eradication of the pathogen in the soil and water systems as well as in growing crops.

\section{Materials and Methods:-}

Bacterial strains: 40 strains of $R$. solanacearum used in this study were isolated from samples collected in different regions of Georgia, mainly in the West and South Georgia (Muradashvili et al, 2012; 2014).

$R$. solanacearum isolates were grown overnight on the Casamino acid-Peptone-Glucose (CPG) broth and agar at $28^{\circ} \mathrm{C}$ temperature during 24 hours in liquid culture, and $36-48 \mathrm{~h}$ on solid media. The strains were stored at the temperature $15-18^{\circ} \mathrm{C}$ in sterile distilled water, also for long - term - in $50 \%$ glycerol $-\mathrm{CPG}(\mathrm{v} / \mathrm{v})$ at $-80^{\circ} \mathrm{C}$.

Antibiotic susceptibility of bacterial isolates was studied by Kirby-Bauer disc-diffusion method. The inhibition zones were measured and were categorized into sensitive (S) and resistant (R) according to the EUcast breakpoints for Gram-negative bacteria, mainly for P.aeruginosa, and also for Enterobacteriaceae (http://www.eucast.org/fileadmin/src/media/PDFs/EUCAST_files/Breakpoint_tables/v_8.0_Breakpoint_Tables.pdf )

Lytic phages were isolated from the river and lake water, also sewage and soil samples using standard enrichment technique (Adams, 1959; Gabrilovich, 1973; Kropinski et al, 2009). Briefly, to $90 \mathrm{ml}$ of a sample (filtered water, sewage or suspended soil) $10 \mathrm{ml}$ of $10 \times$ CPG broth, and $1 \mathrm{ml}$ mid-log phase bacterial culture were added, mixed and incubated at $28^{\circ} \mathrm{C}$ overnight. After adding of $2 \mathrm{ml}$ of chloroform the lysates were kept $1 \mathrm{hr}$ and bacterial debris at room temperature and pelleted by low speed centrifugation. The filtered supernatant was examined for content of phages by spot test to reveal lysis zones. The primary phage lysates were propagated and purified by 5 successive cycles of single plaque-isolation on corresponding bacteria. Phage titers represented by PFU plaqueforming unit (PFU) were assessed using double-layer agar method (M.Gabrilovich,1973; Kropinski et al, 2009).

Morphology of phage particles was examined by TEM according to the standard methods (Ackermann, 2009; Gabrilovich, 1973). The concentrated phage suspensions were placed on carbon /formvar copper grids (Electron Microscopy Sciences, USA), washed with water, negatively stained with $2 \%$ uranyl acetate and examined in the TEM 100SX (JEOL, Japan) operating at $80 \mathrm{kV}$ and standard instrumental magnification 50K.

Host range of phages was determined by spot test registering different grades of lytic activity. Briefly, $10 \mathrm{mkl}$ of phage suspension with the titer $1 \times 10^{8} \mathrm{pfu} / \mathrm{ml}$ was spotted on the lawn or lines of tested bacterial strains and after drying up the plates were incubated at $28 \mathrm{C}$ for $18-24 \mathrm{hrs}$. The lytic reactions such as cl (confluent lysis), ol (opaque lysis), scl (semiconfluent lysis), IP ( individual plaques) were registered.

The lysis stability of selected phages was determined in the liquid culture by the standard methodology of Appelmans (Gabrilovich, 1973) based on estimation of stable lysis time of bacterial liquid culture.

Stability of phages in different media and solutions and sensitivity to chloroform(CHL) was studied by standard methodology (Elbakidze et al, 2015). The sterile filtered phages with the initial titre $1 \times 10^{7}-1 \times 10^{8} \mathrm{pfu} / \mathrm{ml}$ were inoculated in the test solutions (CPG broth, CPG broth $+\mathrm{CHL}$, autoclaved Lisi lake water and the Black Sea water ) and kept at the ambient temperature and at $4^{0} \mathrm{C}$ in the dark with periodic ( 24 hours, 1 week, 2 weeks, 1 month, 6 months) check of phage titre.

\section{Results:-}

Several series of Ralstonia phage isolation have been conducted during 2015-2017. The environmental samples from different sites in Georgia were enriched with 40 Georgian strains of R. solanacearum isolated earlier (Muradashvili et al, 2014; 2015). Out of 95 enriched water and soil samples the primary lysis was observed in 46 samples while confirmed phage - related activity was revealed in 34 samples. These phagelysates (mainly 
mixtures) underwent subsequent cloning and reproduction on susceptible hosts. In the rest 12 samples the phage negative plaques were not obtained and the observed lysis in the spot test was attributed to content of bacteriocin type substances in the primaty lysate.

In total, 25 individual phages active to 31 Georgian isolates of R.solanacearum have been obtained. Majority were isolated during 2015-2016, only 3 phages were obtained in early autumn 2017. Out of 25 phages 20 were isolated by processing of environmental water samples obtained in South and West Georgia, 2 phages were obtained from Mtkvari river in Tbilisi area (central Georgia) and 3 phages - from water samples taken in the East Georgia.

The primary grouping of phages was done based on negative colony morphology and host range. For determination of lytic spectrum, screening of the phage suspensions with the standard titer (see above) was done on the set of 40 strains of R.solanacearum. The phage screening showed coverage of $77.5 \%$ of R.solanacearum collection and obvious diversity among phages. Thirty one test strains of R.solanacearum were lysed by at least one phage from the set of 25 newly isolated Rs bacteriophages. At the same time there was a variation of number of active phages ( from 1 to 19 phages)for particular susceptible strains. High phage susceptibility was observed for several isolates only: R.solanacearum J5A which was lysed by 19 phages simultaneously, R.solanacearum N93 and N62 were susceptible to 16 and 15 phages, and R.solanacearum N4211 and 2A were lysed by 11 and 10 phages respectively. The majority -19 isolates were lysed by 2-7 phages, and 7 strains appeared to be monospecific- lysed by a single phage. A small portion ( 9 isolates) in the set of R.solanacearum strains appeared to be non- susceptible to any of tested phages. The distribution of R.solanacearum isolates by susceptibility to various numbers of Rs phages is presented on the Figure 1.

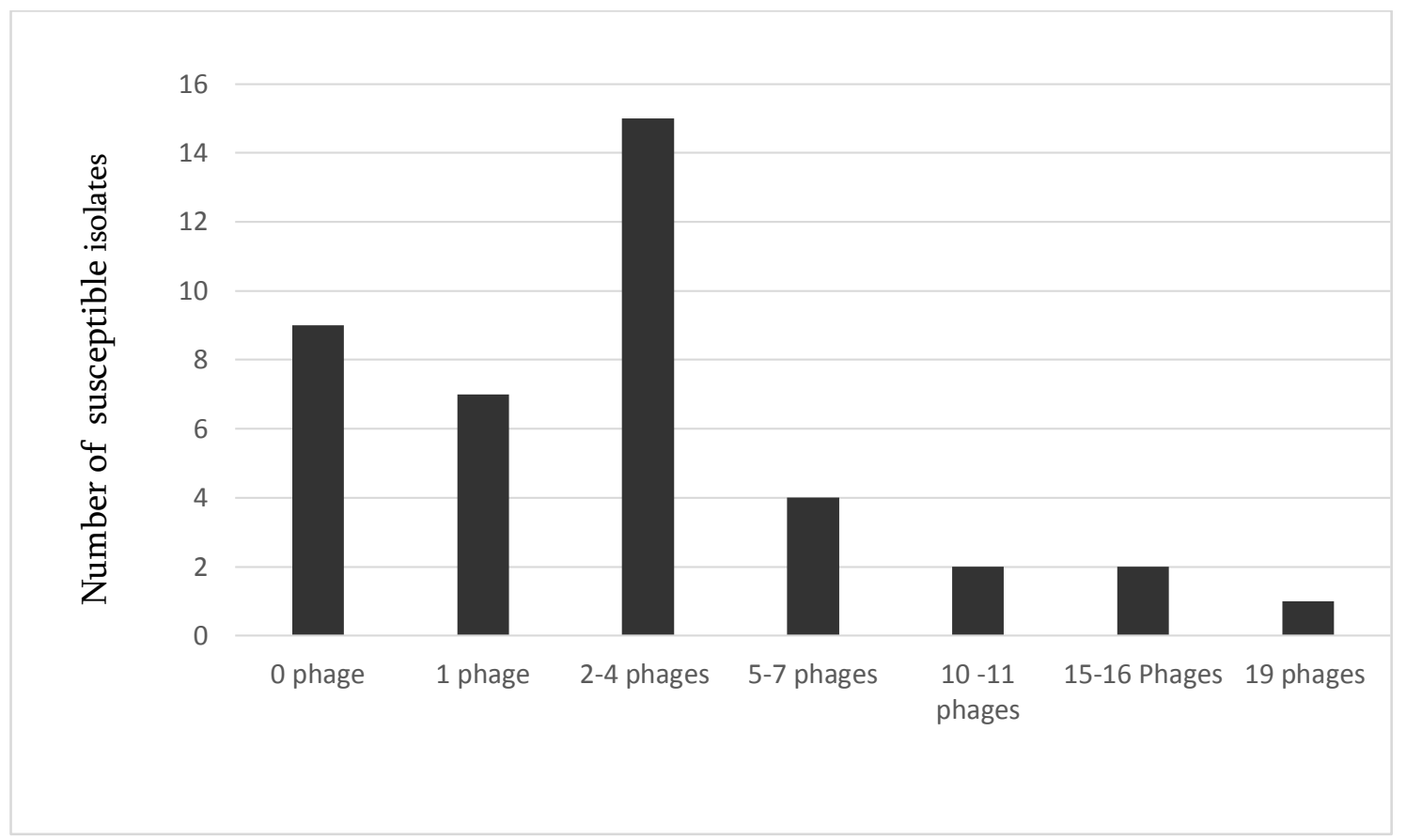

Figure 1:- Phage susceptibility of Georgian strains of R. solanacearum. The results are presented for 40 R.solanacearum strains and 25 Rs phages.

As for the specific host range of individual Rs phages, it varied from $2.5 \%$ to $35 \%$, that can be considered as a narrow to average spectrum of lytic activity. None of the 25 phages showed broad host range, covering more then $50 \%$ of strains. Considerably broad host range was shown for 8 phages: Rs4c (35\%), Rs5 (30\%), Rc 6c and Rs 2$3 \mathrm{o}(27.5 \%$ each), Rs $455 \mathrm{c}$ and Rs 3-1s (25\% for each ), Rs63 and Rs2-2b ( $20 \%$ for each). It should be noted that the lytic spectrum of individual phages appeared to be largely overlapping, that is useful characteristic for construction of a combined phage preparation with broad spectrum lytic activity.

After three steps of purification and the primary characterization 10 bacteriophages ( Rs3-1s, Rs 2-1b, Rs2-2b, Rs2-3o, Rs6c, Rs4c, Rs455c, Rs63, Rs5, Rs11) active to Georgian isolates of R.solanacearum were selected 
mainly based on the lytic spectrum and negative plaque morphology, also good concentration capabilities. The above mentioned bacteriophages were subjected to detailed characterization in order to be used for construction of phage set for detection and subtyping of $R$. solanacaearum isolates, and for creation of therapeutic mixture for biocontol of plant infections caused by $R$. solanacearum.

The study of phage virion ultrastructure by TEM revealed the prevalence of Myoviridae type morphology among R.solanacearum - specific phages. Twenty one phages out of 25 Rs phages were attributed to Myoviridae family with isometric head and contractile tail, although with variable sizes and slightly different shapes (with maximum head size as 100 X90 nm - for phages Rs 2-2b and Rs 3-2o). Two phages (RS5 and Rs 2-1s) were classified as Podoviridae with 55x50nm isometric head and short tail. Two other phages (Rs 6-3 and Rs 3-3c) showed morphology consistent with Siphoviridae family. The TEM images of selected Rs phages are presented on the Figure1. Our results are in agreement with the studies of other investigators where not much diversity has been observed for $\quad R$. solanacearum -specific phages. Mainly Myoviridae morphotype phages were described, some of them belonging to large size Jumbo phages (Toyoda et al, 1991; Fujivara et al, 2011; Matsui et al, 2017).

Table 1:- Basic characteristics of selected phages specific to $R$. solanacearum

\begin{tabular}{|c|c|c|c|c|c|c|c|c|}
\hline \multirow{2}{*}{$\begin{array}{l}\text { R.solanace- } \\
\text { arum } \\
\text { phages }\end{array}$} & \multirow[t]{2}{*}{ Isolation site * } & \multirow{2}{*}{$\begin{array}{l}\text { Isolation } \\
\text { date }\end{array}$} & \multirow[b]{2}{*}{$\begin{array}{l}\text { Host } \\
\text { strain }\end{array}$} & \multirow{2}{*}{$\begin{array}{l}\text { Negative } \\
\text { colony } \\
\text { morphology }\end{array}$} & \multicolumn{3}{|c|}{ Virion morpholohy } & \multirow{2}{*}{$\begin{array}{l}\text { Lytic } \\
\text { spectrum } \\
(\%)\end{array}$} \\
\hline & & & & & Morphotype & $\begin{array}{l}\text { Head } \\
\text { size } \\
\mathrm{nm} * *\end{array}$ & $\begin{array}{l}\text { Tail size } \\
\mathrm{nm} * *\end{array}$ & \\
\hline Rs 3-2c & $\begin{array}{l}\text { SG, Akhaltsikhe } \\
\text { valley }\end{array}$ & 09.2015 & J5a & $\begin{array}{l}\mathrm{D}=3 \mathrm{~mm} \text {, } \\
\text { opaque } \\
\text { with clear } \\
\text { center }\end{array}$ & Myoviridae & $91 \times 91$ & $59 \times 27$ & 14.0 \\
\hline Rs 2-1b & $\begin{array}{l}\text { SG, Tsagveri, } \\
\text { riv. Mujajhela }\end{array}$ & 09.2015 & J5a & $\begin{array}{l}\mathrm{D}=3 \mathrm{~mm} \text {, } \\
\text { opaque } \\
\text { with clear } \\
\text { center }\end{array}$ & Myoviridae & $\begin{array}{l}100 \\
X 91\end{array}$ & $\begin{array}{l}113,5 \\
X 18\end{array}$ & 9.0 \\
\hline Rs 11 & $\begin{array}{l}\text { WG, Khulo, } \\
\text { riv.Acharistskhali }\end{array}$ & 09.2015 & 63 & $\begin{array}{l}\mathrm{D}=1 \mathrm{~mm} \\
\text { Pinpoint } \\
\text { opaque }\end{array}$ & Myoviridae & $\begin{array}{l}94,5 \\
\times 91\end{array}$ & $\begin{array}{l}122,5 \\
X 22,5\end{array}$ & 2.0 \\
\hline Rs 3-1b & $\begin{array}{l}\text { SG, Akhaltsikhe } \\
\text { valley }\end{array}$ & 07.2016 & $\mathrm{~J} 5 \mathrm{~A}$ & $\begin{array}{l}\mathrm{D}=2,5 \mathrm{~mm} \\
\text { opaque } \\
\text { with clear } \\
\text { center }\end{array}$ & Myoviridae & $\begin{array}{l}90,5 \mathrm{X} \\
82\end{array}$ & $\begin{array}{l}118 \\
X 22,5\end{array}$ & 14.0 \\
\hline Rs 3-1s & $\begin{array}{l}\text { SG, Akhaltsikhe } \\
\text { valley }\end{array}$ & 07.2016 & $\mathrm{~J} 5 \mathrm{~A}$ & $\begin{array}{l}\mathrm{D}=2,5- \\
3 \mathrm{~mm} \\
\text { opaque } \\
\text { with clear } \\
\text { center }\end{array}$ & Myoviridae & $\begin{array}{l}91 \mathrm{X} \\
86,5\end{array}$ & $\begin{array}{l}105 \\
\text { X18,5 }\end{array}$ & 26.0 \\
\hline Rs $2-2 b$ & $\begin{array}{l}\text { SG, Tsagveri, } \\
\text { riv. Mujajhela }\end{array}$ & 06.2016 & $\mathrm{~J} 5 \mathrm{~A}$ & $\begin{array}{l}\mathrm{D}=1,5- \\
2 \mathrm{~mm} \\
\text { opaque } \\
\text { with clear } \\
\text { center }\end{array}$ & Myoviridae & $\begin{array}{l}90 \\
X 82\end{array}$ & $\begin{array}{l}127 \\
X 18,5\end{array}$ & 16.0 \\
\hline Rs 2-2s & $\begin{array}{l}\text { SG, Tsagveri, } \\
\text { riv. Mujajhela }\end{array}$ & 06.2016 & $\mathrm{~J} 5 \mathrm{~A}$ & $\begin{array}{l}\mathrm{D}=1- \\
1,5 \mathrm{~mm} \\
\text { opaque }\end{array}$ & Myoviridae & $\begin{array}{l}95,5 \\
\times 91\end{array}$ & $\begin{array}{l}113,5 \\
\times 18\end{array}$ & 16.0 \\
\hline Rs 6c & $\begin{array}{l}\text { CG, } \quad \text { Tbilisi } \\
\text { surroundings, } \\
\text { riv.Mtkvari }\end{array}$ & 07.2016 & 63 & $\begin{array}{l}\mathrm{D}=2- \\
2,5 \mathrm{~mm} \\
\text { clear with } \\
\text { shadow }\end{array}$ & Myoviridae & $\begin{array}{l}91 \\
X 86\end{array}$ & $\begin{array}{l}113,5 \quad X \\
18,5\end{array}$ & 23.0 \\
\hline Rs 4c & $\begin{array}{l}\text { WG, Kobuleti, } \\
\text { riv. Atchkva }\end{array}$ & 03.2016 & 63 & $\begin{array}{l}\mathrm{D}=2 \mathrm{~mm} \\
\text { opaque }\end{array}$ & Myoviridae & $90 \times 60$ & $\begin{array}{l}115 \\
X 18,5\end{array}$ & 30.0 \\
\hline
\end{tabular}




\begin{tabular}{|c|c|c|c|c|c|c|c|c|}
\hline & & & & $\begin{array}{l}\text { with clear } \\
\text { center }\end{array}$ & & & & \\
\hline Rs 455c & $\begin{array}{l}\text { WG, Kobuleti, } \\
\text { Riv. Atchkva }\end{array}$ & 03.2016 & $2 \mathrm{~A}$ & $\begin{array}{l}\mathrm{D}=2,5 \mathrm{~mm} \\
\text { opaque } \\
\text { with clear } \\
\text { center }\end{array}$ & Myoviridae & $91 \times 77$ & $\begin{array}{l}100 \\
X 18,5\end{array}$ & 23.0 \\
\hline Rs 6-3 & $\begin{array}{l}\text { WG,Kobuleti, } \\
\text { Marine water }\end{array}$ & 09.2016 & J5a & $\begin{array}{l}\mathrm{D}=3 \quad \mathrm{~mm} \\
\text { clear with } \\
\text { shedow }\end{array}$ & Siphoviridae & $55 \times 50$ & $\begin{array}{l}181 \\
X 13,5\end{array}$ & 21.0 \\
\hline Rs 5 & $\begin{array}{l}\text { WG, Kobuleti, } \\
\text { riv. Atchkva }\end{array}$ & 03.2016 & J5a & $\begin{array}{l}\mathrm{D}=5 \mathrm{~mm} \\
\text { clear with } \\
\text { opaque } \\
\text { center }\end{array}$ & Podoviridae & $60 \times 55$ & $18 X 12$ & 21.0 \\
\hline Rs 2-3o & $\begin{array}{l}\text { SG, Tsagveri, } \\
\text { riv. Mujajhela }\end{array}$ & 03.2016 & J5a & $\begin{array}{l}\mathrm{D}=1,5- \\
2 \mathrm{~mm} \\
\text { opaque } \\
\text { with clear } \\
\text { center }\end{array}$ & Myoviridae & $100 \times 82$ & $113,5 \times 23$ & 18.6 \\
\hline Rs 63 & $\begin{array}{l}\text { CG,Tbilisi } \\
\text { surroundings, } \\
\text { riv.Mtkvari }\end{array}$ & 10.2016 & 97 & $\begin{array}{l}\mathrm{D}=2,5 \mathrm{~mm} \\
\text { opaque } \\
\text { with clear } \\
\text { center }\end{array}$ & Myoviridae & $91 \times 69$ & $\begin{array}{l}123 \\
X 22,5\end{array}$ & 2.5 \\
\hline
\end{tabular}

*SG- South Georgia; WG -West Georgia; CG-Central Georgia; ** average of measurement of 3 phage particles

One of important characteristics of phages, especially those to be used for biocontrol of bacterial pathogens, is their capability to produce stable lysis of bacterial culture and the low rate of phage resistance in bacteria. Selected 10 individual phages showed 8-12 hrs of lysis stability in the liquid culture ( detailed data not shown here) that indicates considerably low frequency of development of phage resistance in the host bacteria.

From the set of $10 R$. solanacearum-specific phages 4 phages (Rs4c,Rs5,Rs6c, Rs455c), which demonstrated most of the required properties, were used for construction of therapeutic phage mixture for experimental studies on potato plants (M. Tediashvili et al, manuscript in preparation, 2018). The preliminary in vitro testing included estimation of antibacterial efficacy, stability in different solutions and viability under changeable physical-chemical factors. Here we present data on stability for components of experimental phage consortium in various solutions, natural sea and lake water based on viable phage counts. The experiments showed (Table 2) that all 4 Rs bacteriophages expressed obvious stability during 6 months in various solutions and natural water samples. Only a slight decrease (up to $1 \mathrm{log}$ ) in phage titer was observed. Also, chloroform had no affect on viability of these phages. All the above mentioned properties are necessary characteristics for bacteriophages to be used for infection control in an open environment. In addition, the $24 \mathrm{hr}$ lysis stability in liquid culture for the combination of 4 individual phages (Rs4c, Rs5, Rs6c, Rs455c) was registered. Although this mixture as an experimental therapeutic preparation was shown to be sufficiently effective in the laboratory bioassays on potato tuber discs and in the challenge experiments in greenhouses on potato plants (data not presented in this paper), the necessity of further regular improvement of this characteristic, e.g. through selection of phage host range mutants, should be taken into consideration.

For comparative estimation of antibacterial potential of specific bacteriophages and other antimicrobial substances we conducted parallel screenings of lytic activity of 10 selected bacteriophages and 10 commonly used antibiotics towards $R$. solanacearum strains in order to asses correlation ( if any) between these two antibacterial means. The results of the study (Table 3) showed high resistance of the Georgian isolates of R.solanacearum to the tested antibiotics. All strains showed multiple resistance patterns (resistance to more then 5 antibiotics) and among them 10 strains $(25 \%)$ demonstrated resistance to all 10 antibiotics. Streptomycin, the antibiotic widely used in the agricultural practices not too long ago, was active only towards 3 strains. At the same time, as mentioned above, only 9 strains out of 40 were non-susceptible to Rs phages. While comparing side by side the antibiotic and phage susceptibility of R.solanacearum isolates no correlation can be seen. Antibiotic resistant strains were mainly still susceptible to phages, and visa versa. For example, 7 out of 10 strains of $R$. solanacearum, totally resistant to antibiotics, were lysed by 2-5 Rs phages and 6 out of 9 phage-resistant strains were susceptible to at least 1 
antibiotic. Only 3 strains out of 40 appered to be resistant to both - phages and antibiotics. All this once again indicates the potential of phage application as alternative or supplement to antibiotic treatment.

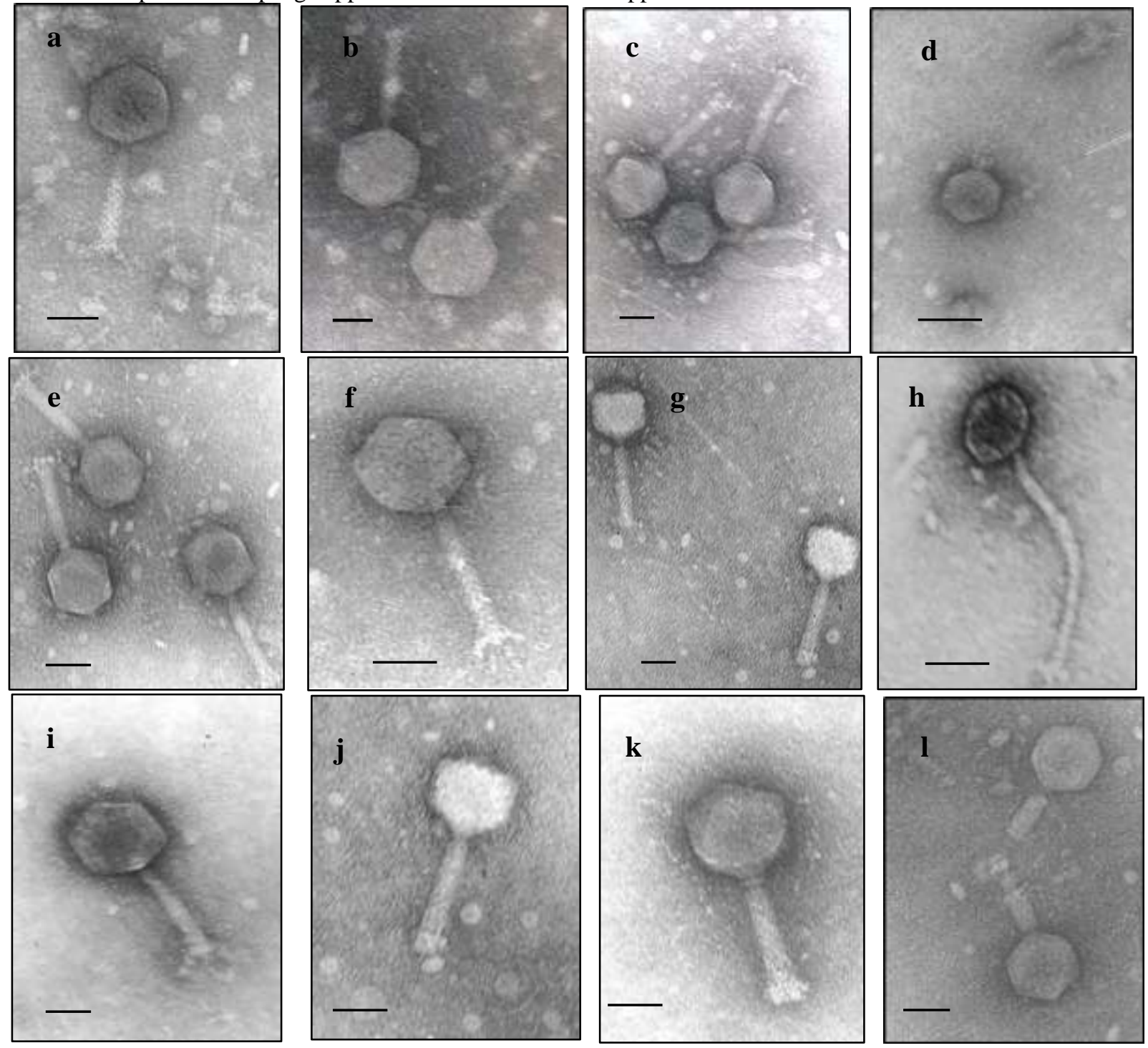

Figure1:- TEM images of selected bacteriophages specific to R.solanacearum: a) Rs 2-2b; b) Rs 2-1b; c) Rs 2-3o; d)Rs5; e)Rs11; f)Rs6c; g)Rs4c; h)Rs6-3; i)Rs3-1s; j) Rs455c; k)Rs63; l)Rs3-2c.

TEM JEOL 100SX; Instrumental magnification 50K; bar indicates $50 \mathrm{~nm}$;

Table 2:- Stability of selected R.solanacearum phages in different solutions

\begin{tabular}{|c|c|c|c|c|c|c|c|}
\hline \multirow{2}{*}{$\begin{array}{l}\text { R.solanacearum } \\
\text { Bacteriophages }\end{array}$} & \multirow[t]{2}{*}{ Time } & \multicolumn{6}{|c|}{ Phage counts (PFU/ml) in different media and solutions* } \\
\hline & & $\begin{array}{l}\text { CPG broth } \\
4^{\circ} \mathrm{C}\end{array}$ & $\begin{array}{l}\text { CPG } \\
\text { broth }+ \text { CHL } \\
4^{\circ} \mathrm{C}\end{array}$ & $\begin{array}{l}\mathrm{CPG} \\
\text { broth } \\
22^{\circ} \mathrm{C} \\
\end{array}$ & $\begin{array}{l}\text { PBS } \\
\text { buffer } 4^{\circ} \mathrm{C}\end{array}$ & $\begin{array}{l}\text { Lake } \\
\text { water } \\
4^{\circ} \mathrm{C} \\
\end{array}$ & $\begin{array}{l}\text { Sea } \\
\text { water } \\
4^{\circ} \mathrm{C} \\
\end{array}$ \\
\hline \multirow{6}{*}{ Rs 6c } & 0 hour & $2,4 \times 10^{7}$ & $2,8 \times 10^{7}$ & $3,1 \times 10^{7}$ & $1,9 \times 10^{7}$ & $2,5 \times 10^{7}$ & $2,1 \times 10^{7}$ \\
\hline & 24 hours & $9 \times 10^{6}$ & $7 \times 10^{6}$ & $6 \times 10^{6}$ & $6 \times 10^{6}$ & $2 \times 10^{6}$ & $6 \times 10^{6}$ \\
\hline & 1 week & $6 \times 10^{6}$ & $5 \times 10^{7}$ & $6 \times 10^{6}$ & $4 \times 10^{6}$ & $5 \times 10^{6}$ & $4 \times 10^{6}$ \\
\hline & 2 weeks & $2 \times 10^{6}$ & $4 \times 10^{6}$ & $9 \times 10^{6}$ & $9 \times 10^{6}$ & $4 \times 10^{5}$ & $2 \times 10^{6}$ \\
\hline & 1 month & $1,9 \times 10^{7}$ & $1,2 \times 10^{\top}$ & $5 \times 10^{7}$ & $1,2 \times 10^{7}$ & $8 \times 10^{6}$ & $1 \mathrm{X} 10^{\top}$ \\
\hline & 6 months & $6 \times 10^{7}$ & $4 \times 10^{7}$ & $2 \times 10^{7}$ & $3 \times 10^{7}$ & $1 \mathrm{X} 10^{7}$ & $2 \times 10^{7}$ \\
\hline \multirow[t]{2}{*}{ Rs 5c } & 0 hour & $1,3 \times 10^{8}$ & $1 \mathrm{X} 10^{8}$ & $1,2 \times 10^{8}$ & $9 \times 10^{7}$ & $1,4 \mathrm{X} 10^{8}$ & $9 \times 10^{7}$ \\
\hline & 24 hours & $9 \times 10^{7}$ & $7 \times 10^{6}$ & $8 \times 10^{7}$ & $6 \times 10^{7}$ & $6 \times 10^{7}$ & $9 \times 10^{7}$ \\
\hline
\end{tabular}




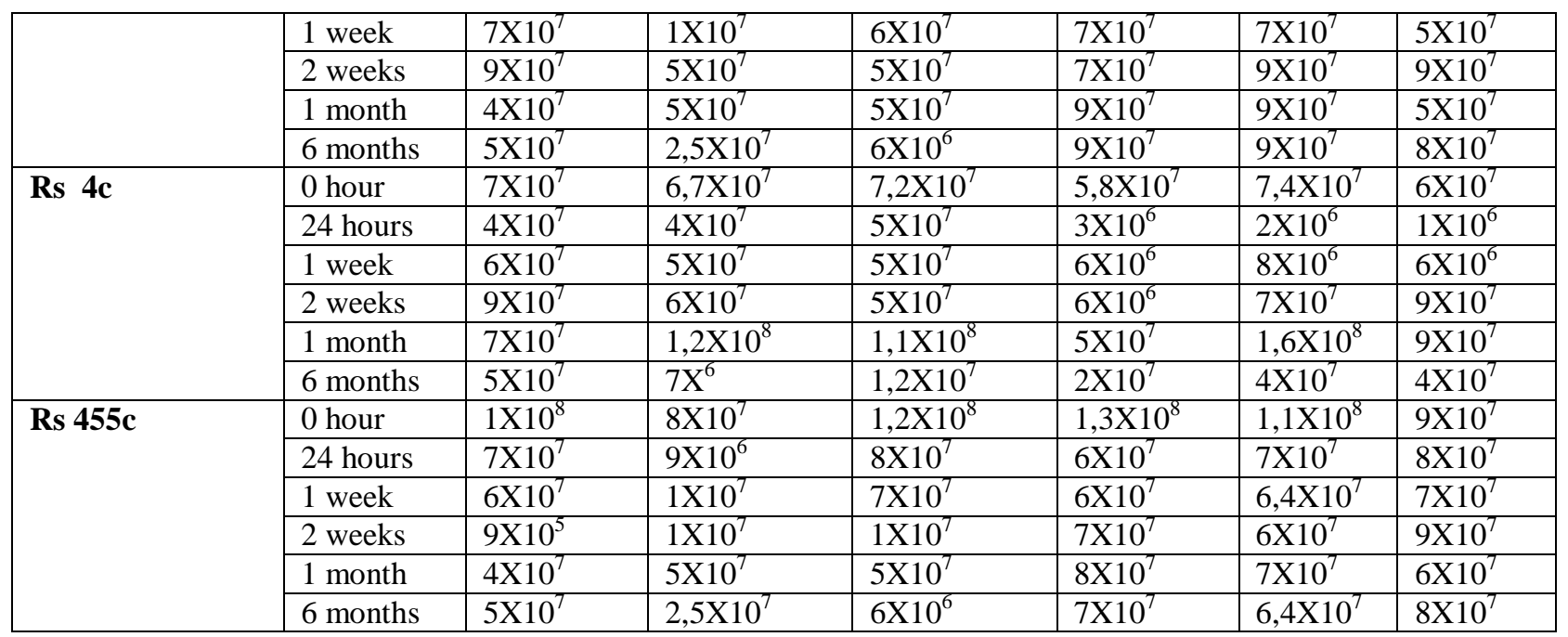

*Determined by double layer method; average of two parallel measurements.

Table 3:- Comparative susceptibility of R.solanacearum Georgian isolates to antibiotics and bacteriophages

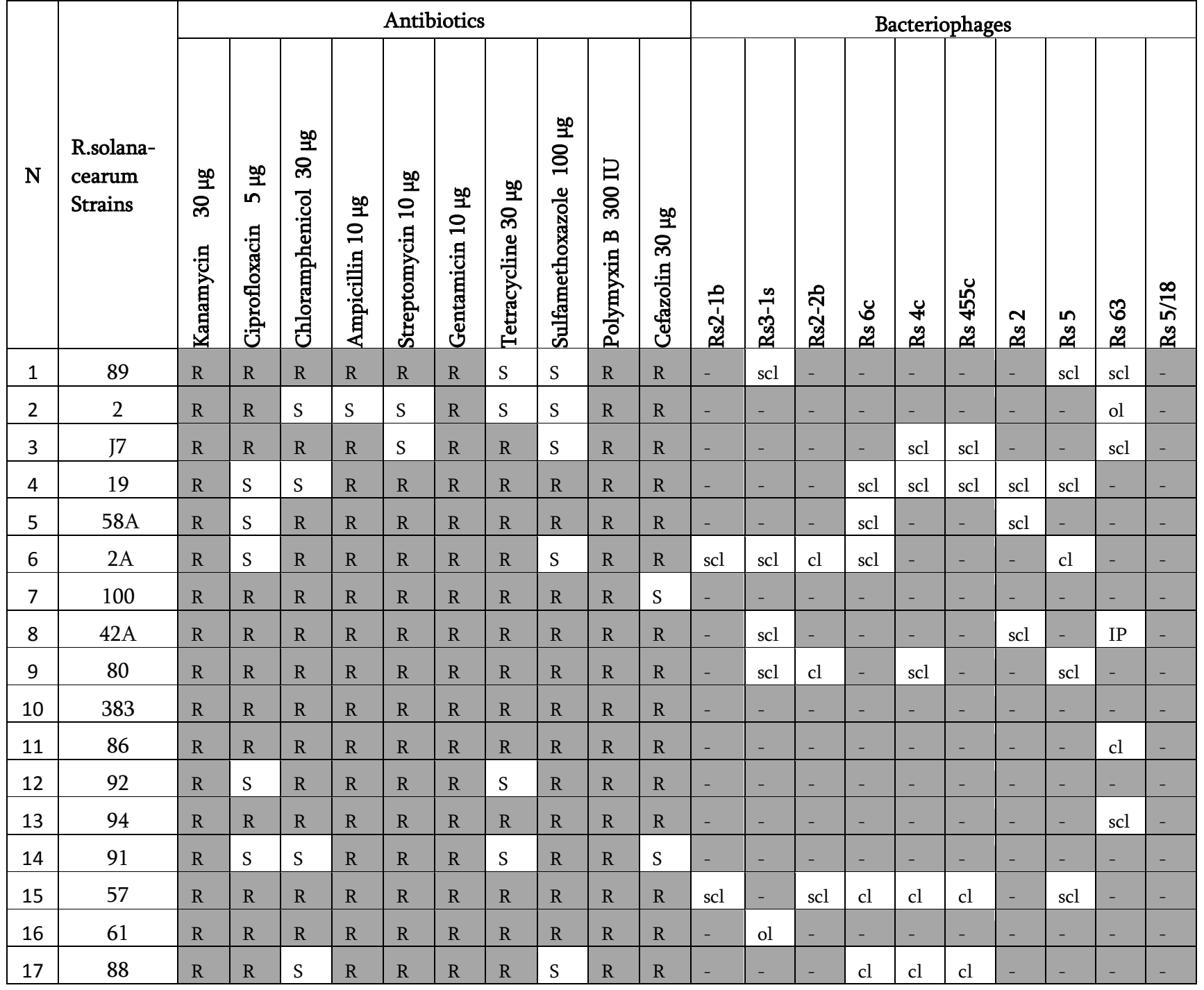




\begin{tabular}{|c|c|c|c|c|c|c|c|c|c|c|c|c|c|c|c|c|c|c|c|c|c|}
\hline 18 & 43 & $\mathrm{R}$ & $\mathrm{R}$ & $\mathrm{S}$ & $\mathrm{R}$ & $\mathrm{R}$ & $\mathrm{R}$ & $\mathrm{R}$ & $\mathrm{R}$ & $\mathrm{R}$ & $\mathrm{R}$ & - & $\mathrm{scl}$ & $\mathrm{scl}$ & - & - & - & scl & scl & - & - \\
\hline 19 & 5 & $\mathrm{R}$ & $S$ & S & $\mathrm{R}$ & $\mathrm{R}$ & $\mathrm{R}$ & S & S & $\mathrm{R}$ & $\mathrm{R}$ & - & - & - & - & - & - & $\mathrm{cl}$ & - & - & - \\
\hline 20 & 3725 & $\mathrm{R}$ & $S$ & $\mathrm{R}$ & $\mathrm{R}$ & $\mathrm{R}$ & $\mathrm{S}$ & S & $\mathrm{R}$ & $\mathrm{R}$ & $\mathrm{R}$ & IP & - & - & - & - & - & $\mathrm{cl}$ & - & - & - \\
\hline 21 & 4211 & $\mathrm{R}$ & S & $\mathrm{R}$ & $\mathrm{R}$ & $\mathrm{R}$ & $\mathrm{R}$ & $\mathrm{R}$ & $\mathrm{R}$ & $\mathrm{R}$ & $\mathrm{R}$ & - & ol & ol & - & IP & - & - & ol & - & ol \\
\hline 22 & 63 & $\mathrm{R}$ & $\mathrm{R}$ & $\mathrm{S}$ & $\mathrm{R}$ & $\mathrm{R}$ & $\mathrm{R}$ & $\mathrm{R}$ & $\mathrm{R}$ & $\mathrm{R}$ & $\mathrm{R}$ & - & - & - & $\mathrm{cl}$ & $\mathrm{cl}$ & $\mathrm{cl}$ & $\mathrm{cl}$ & - & - & - \\
\hline 23 & 48 & $S$ & $\mathrm{R}$ & $\mathrm{R}$ & $\mathrm{R}$ & $\mathrm{R}$ & $\mathrm{R}$ & $\mathrm{R}$ & $\mathrm{R}$ & $\mathrm{R}$ & $\mathrm{R}$ & - & - & - & - & - & - & - & - & - & - \\
\hline 24 & 4214 & $\mathrm{R}$ & $\mathrm{R}$ & $\mathrm{R}$ & $\mathrm{R}$ & $\mathrm{R}$ & $\mathrm{R}$ & $\mathrm{R}$ & $\mathrm{R}$ & $\mathrm{R}$ & $\mathrm{R}$ & IP & - & - & - & - & - & - & - & - & - \\
\hline 25 & 93 & $S$ & $\mathrm{~S}$ & $\mathrm{~S}$ & $\mathrm{R}$ & $\mathrm{R}$ & $\mathrm{R}$ & $\mathrm{S}$ & $\mathrm{S}$ & $\mathrm{R}$ & $\mathrm{R}$ & $\mathrm{scl}$ & $\mathrm{scl}$ & $\mathrm{scl}$ & - & - & - & - & $\mathrm{cl}$ & - & - \\
\hline 26 & $\mathrm{~J} 3$ & $\mathrm{R}$ & $\mathrm{R}$ & $\mathrm{S}$ & $\mathrm{R}$ & $\mathrm{R}$ & $\mathrm{R}$ & $\mathrm{R}$ & $\mathrm{R}$ & $\mathrm{R}$ & $\mathrm{R}$ & - & - & - & $\mathrm{cl}$ & IP & $\mathrm{cl}$ & - & - & - & - \\
\hline 27 & 5 & $\mathrm{R}$ & $\mathrm{S}$ & $\mathrm{R}$ & $\mathrm{R}$ & $\mathrm{R}$ & $\mathrm{R}$ & $S$ & $\mathrm{~S}$ & $\mathrm{R}$ & $\mathrm{R}$ & - & - & - & $\mathrm{cl}$ & $\mathrm{cl}$ & $\mathrm{cl}$ & - & $\mathrm{cl}$ & - & - \\
\hline 28 & 325 & $\mathrm{R}$ & $\mathrm{S}$ & $\mathrm{R}$ & $\mathrm{R}$ & $\mathrm{R}$ & $\mathrm{R}$ & $S$ & $\mathrm{~S}$ & $\mathrm{R}$ & $\mathrm{R}$ & - & - & - & - & ol & - & - & - & ol & - \\
\hline 29 & 55 & $\mathrm{R}$ & $\mathrm{S}$ & $S$ & $\mathrm{R}$ & $\mathrm{R}$ & $\mathrm{S}$ & $\mathrm{S}$ & $\mathrm{R}$ & $\mathrm{R}$ & $\mathrm{R}$ & - & - & - & $\mathrm{cl}$ & $\mathrm{cl}$ & $\mathrm{cl}$ & $\mathrm{cl}$ & - & & - \\
\hline 30 & 42 & $\mathrm{R}$ & $\mathrm{R}$ & $\mathrm{R}$ & $\mathrm{R}$ & $\mathrm{R}$ & $\mathrm{R}$ & $\mathrm{R}$ & $\mathrm{R}$ & $\mathrm{R}$ & $\mathrm{R}$ & - & - & - & - & - & - & - & - & - & - \\
\hline 31 & 46 & $\mathrm{R}$ & $\mathrm{S}$ & $S$ & $\mathrm{R}$ & $\mathrm{R}$ & $\mathrm{R}$ & $\mathrm{R}$ & $\mathrm{S}$ & $\mathrm{R}$ & $\mathrm{R}$ & - & - & - & - & scl & $\mathrm{scl}$ & $\mathrm{cl}$ & IP & - & - \\
\hline 32 & 46 & $\mathrm{R}$ & $\mathrm{S}$ & $\mathrm{S}$ & $\mathrm{R}$ & $\mathrm{R}$ & $\mathrm{R}$ & $\mathrm{S}$ & $\mathrm{S}$ & $S$ & $\mathrm{R}$ & - & - & - & - & - & - & - & - & - & - \\
\hline 33 & 47 & $\mathrm{R}$ & $\mathrm{R}$ & $\mathrm{R}$ & $\mathrm{R}$ & $\mathrm{R}$ & $\mathrm{R}$ & $S$ & $S$ & $\mathrm{R}$ & $\mathrm{R}$ & - & - & - & - & - & - & - & - & - & - \\
\hline 34 & 67 & $\mathrm{R}$ & $\mathrm{R}$ & $\mathrm{R}$ & $\mathrm{R}$ & $\mathrm{R}$ & $\mathrm{R}$ & $\mathrm{R}$ & $\mathrm{R}$ & $\mathrm{R}$ & $\mathrm{R}$ & - & - & - & - & - & - & $\mathrm{cl}$ & - & - & - \\
\hline 35 & 99 & $\mathrm{R}$ & $S$ & $\mathrm{~S}$ & $\mathrm{R}$ & $\mathrm{R}$ & $\mathrm{R}$ & $\mathrm{R}$ & $\mathrm{S}$ & $\mathrm{R}$ & $\mathrm{R}$ & - & - & - & - & - & - & - & - & - & - \\
\hline 36 & $\mathrm{~J} 5$ & $\mathrm{R}$ & $S$ & $\mathrm{R}$ & $\mathrm{R}$ & $\mathrm{R}$ & $\mathrm{R}$ & $\mathrm{R}$ & $S$ & $\mathrm{R}$ & $\mathrm{R}$ & $\mathrm{scl}$ & $\mathrm{scl}$ & scl & $\mathrm{cl}$ & - & - & - & $\mathrm{cl}$ & - & - \\
\hline 37 & 18 & $\mathrm{~S}$ & $\mathrm{R}$ & $\mathrm{R}$ & $\mathrm{R}$ & $\mathrm{R}$ & $\mathrm{R}$ & $\mathrm{R}$ & $\mathrm{R}$ & $\mathrm{R}$ & $\mathrm{R}$ & - & - & - & - & - & - & $\mathrm{cl}$ & - & - & - \\
\hline 38 & 97 & $\mathrm{R}$ & $\mathrm{R}$ & $\mathrm{S}$ & $\mathrm{R}$ & $\mathrm{R}$ & $\mathrm{R}$ & $\mathrm{R}$ & $\mathrm{S}$ & $\mathrm{R}$ & $\mathrm{R}$ & - & - & - & - & ol & - & - & - & - & ol \\
\hline 39 & 62 & $\mathrm{R}$ & $\mathrm{R}$ & S & $\mathrm{R}$ & $\mathrm{R}$ & $\mathrm{R}$ & $S$ & S & $\mathrm{R}$ & $\mathrm{R}$ & $\mathrm{scl}$ & scl & scl & - & - & - & - & scl & - & - \\
\hline 40 & $\mathrm{~J} 2$ & $\mathrm{R}$ & $S$ & $\mathrm{~S}$ & $\mathrm{R}$ & $S$ & $\mathrm{R}$ & $\mathrm{R}$ & $\mathrm{R}$ & $\mathrm{R}$ & $\mathrm{R}$ & - & - & - & $\mathrm{cl}$ & $\mathrm{scl}$ & $\mathrm{cl}$ & - & - & scl & - \\
\hline
\end{tabular}

R- resitant; S- sensitive; cl-confluent lysis; ol-opaque lysis; scl- semi-confluent lysis; IP-individual plaques.

\section{Discussion:-}

Many authors agree that the role of the phage therapy for the plant protection can increase in the future as a part of an integrated disease management strategy, along with genetic, cultural, biological, and chemical control (Balog et al, 2010; Alvarez \& Biosca ,2017). Since currently there is no promising control method and/or mean for bacterial wilt, phage therapy could serve as novel efficient approach, at least supplementing existing methods. This can be especially important for areas where the bacterium has been established recently and the first strategy should aim to prevent introduction and, if inadvertently introduced, subsequent movement of the pathogen.

For practical applications of phages first of all the construction of research collection of virulent phages is required -as a reserve for creation of effective therapeutic preparation for prevention of disease development or targeting particular outbreaks and strains of pathogens. In the infection control high specificity of bacteriophages can be considered as both - advantage and disadvantage (Chanishvili et al, 2001; Bae et al, ) since specific phages do not harm normal flora or surrounding environmental microbiolota, while narrow lytic spectrum enables easier development of phage resistance. For massive use as biocontrol agents in plants, mainly combination of several phages with different host range has been proposed based on the phage therapy experience in medicine and veterinary(Chanishvili et al, 2001; Chanishvili \&Sharp, 2009), although some researchers showed efficacy of application of single virulent phages specific to particular strains on particular plant(s) in controlled experiments on bacterial wilt (Bae et al, 2010; Alvarez \& Biosca ,2017).

The present study reports on isolation and characterization of lytic bacteriophages specific to Georgian strains of $R$. solanacearum of race 3 , bioavar 2 . The selected 4 phages out of 25 phages isolated form environmental samples in Georgia were included in the experimental mixture and the efficacy was examined on potato tuber discs and in 
vivo experiments on growing potato plants ( M.Tediashvili et al, 2018, manuscript in preparation). A promising probability of phage application on seed material and young plants, resulting in lowering number of diseased plants or delay in disease development, depending on treatment regimen, was shown.

For better efficacy and reliability of phage -based biocontol of bacterial infections of plants a number of approaches can be recommended: i) increase coverage of possible varieties of target pathogens - though regular screenings on emerging strains and enrichment of phage mixtures with different lytic phages; ii)minimize the development of phage resistance in bacteria - by applying phage mixtures and broad host-range mutant phages; iii) increase stability of phage preparations in the environment by employing protective formulations, avoiding sunlight, high acidity etc.

\section{References:-}

1. Alvarez B. \& E. G. Biosca (2017). Bacteriophage-Based Bacterial Wilt Biocontrol for an Environmentally Sustainable Agriculture. Frontiers in Plant Science (www.frontiersin.org ), July 2017, Vol. 8 , Art 1218.

2. Ackerman H.W.2009. Phage Classification and Characterization”. In: Bacteriophages, Methods and Protocols". Volume 1. Isolation, Characterization and interactions" (Ed. M.R.J. Clokie, A.M. Kropinski) 2009, Humana Press. Chapter 13,pp. 127-140.

3. Adams, M.H. 1959. Bacteriophages. Interscience Publishers, New York

4. Bae Ju Young, Jing Wu, Hyoung Ju Lee, Eun Jeong Jo, Senthilkumar Murugaiyan, Eunsook Chung, and SeonWoo Lee ( 2012). Biocontrol Potential of a Lytic Bacteriophage PE204 against Bacterial Wilt of Tomato. J. Microbiol. Biotechnol., 22(12), 1613-1620.

5. Balogh, B., J. B. Jones, F. B. Iriarte, and M. T. Momol (2010). Phage therapy for plant disease control. Curr. Pharm. Biotechnol. 11: 48-57.

6. Champoiseau, P. G., Jones, J. B., and Allen, C. (2009). Ralstonia solanacearum race 3 biovar 2 causes tropical losses and temperate anxieties. Plant Health Progress doi:10.1094/PHP-2009-0313-01-RV.

7. Chanishvili N, T.Chanishvili, M.Tediashvili \& P. A.Barrow (2001).Phages and their application against drugresistant bacteria. Review. J. Che,.Technol. Biotechnol., 76: 689-699.

8. Chanishvili N. \& R.Sharp (2009). A literature review of the practical application of bacteriophage research. Eliava Institute of Bacteriophage, Microbiology and Virology, Tbilisi, Georgia.

9. Elbakidze T., Kokashvili T., Janelidze N., Porchkhidze K., Koberidze T., Tediashvili M. (2015). Biological characterization of V.cholerae - specific bacteriophages isolated from water sources in Georgia. GMN, No 3 (240), pp. 65-72.

10. Elphinstone, J.G. (2005). The current bacterial wilt situation: a global overview. In C. Allen, P. Prior and A.C. Hayward (ed.),Bacterial Wilt Disease and the Ralstonia solanacearum Species Complex. American Phytopathological Society Press, St. Paul, MN, pp. 9-28.

11. Fegan, M. and P. Prior. (2005). How complex is the Ralstonia solanacearum species complex?, pp. 449-462. In C. Allen, P. Prior, and A. C. Hayward (eds.). Bacterial Wilt Disease and the Ralstonia solanacearum Species Complex. APS Press, St. Paul, MN.

12. Fujiwara, A., M. Fujisawa, R. Hamasaki, T. Kawasaki, M. Fujie, and T. Yamada (2011). Biocontrol of Ralstonia solanacearum by treatment with lytic bacteriophages. Appl. Environ. Microbiol. 77: 4155-416

13. Gabrilovich M. (1973). Basics of bacteriophages research (in Russian). "Visheishaya Schkola", Minsk.

14. Kropinski A., A.Mazzacco, T. Waddel E Lingohr and R. Jonson(2009). "Enumeration of Bacteriophages by Double Agar Overlay Plaque Assay". In: Bacteriophages, Methods and Protocols". Volume 1. Isolation Characterization and interactions" (Ed. M.R.J. Clokie, A.M. Kropinski) 2009, Humana Press, Chapter 7. Pp. 6980 .

15. Lashkhi N., M. Tediashvili, E . Jaiani, T. Koberidze, N. Chanishvili, G.Tsertsvadze (2003). In vitro antibacterial activity of bacteriophages specific to Ralstonia solanacearum, Abstracts, 103rd ASM General meeting, May 1822, 2003, Washington, D.C. (USA)., p 393 .

16. Mansfied, J., S. Genin, S. Magor, et al (2012). Top 10 plant pathogenic bacteria in molecular plant pathology. Mol. Plant Pathol. 13:614- 629.

17. Matsui T, Yoshikawa G, Mihara T, Chatchawankanphanich O,Kawasaki T, Nakano M, Fujie M,Ogata H and Yamada T (2017) .Replications of Two Closely Related Groups of Jumbo Phages Show Different Level of Dependence on Host-encoded RNA Polymerase. Front. Microbiol. 8:1010. doi: 10.3389/fmicb.2017.01010.

18. Mepharishvili G., Sikharulidze Z., Thwaites R., Tsetskhladze T.,Dumbadze R., Gabaidze M., Muradashvili M.( 2012). New Disease Reports 25: 16. [doi:10.5197/j.2044-0588.2012.025.016 
19. Muradashvili M., G. Meparishvili, Z. Sikharulidze and S. Meparishvili ( 2014). First report of potato brown rot caused by Ralstonia solanacearum in Georgia. J Plant Pathol, 96 (4, Supplement), S4.113-S4.131.

20. Muradashvili M.T., G.V. Merabishvili, M.I. Tediashvili, Z.V. Sikharulidze (2015). Phenotypic peculiarities of Georgian isolates of Ralstonia solanacearum. Annals of Agrarian Sciences, v.13, No. 3, pp.20-25.

21. Ramesh R., and G.S. Phadke (2012). Rhizosphere and endophytic bacteria for the suppression of eggplant wilt caused by Ralstonia solanacearum. Crop Prot. 37:35-41.

22. Toyoda, H., K. Kakutani, S. Ikeda, S. Goto, H. Tanaka, and S. Ouchi (1991). Characterization of deoxyribonucleic acid of virulent bacteriophage and its infectivity to host bacteria,Pseudomonas solanacearum. J. Phytopathol. 131: 11-21.

23. Yamada, T., T. Kawasaki, S. Nagata, A. Fujiwara, S. Usami, and M. Fujie. 2007. New bacteriophages that infect the phytopathogen Ralstonia solanacearum. Microbiology. 153: 2630:2639.

24. Yuliar Y. A. Nion, and K. Toyota (2015). Recent Trends in Control Methods for Bacterial Wilt Diseases Caused by Ralstonia solanacearum. Microbes Environ. 30 (1):1-11.

25. Champoiseau, P. G., Jones, J. B., and Allen, C. 2009. Ralstonia solanacearum race 3 biovar 2 causes tropical losses and temperate anxieties. Plant Health Progress doi:10.1094/PHP-2009-0313-01-RV.

\section{Acknowledgment:-}

The presented work was conducted in the frames of the Shota Rustaveli National Science Foundation grant project \# FR 460/10-101/14. 